\title{
Rhetoric and Platonism in Fifth-Century Athens
}

There are reasons to believe that relations between Platonism and rhetoric in Athens during the fifth century CE were rather close. ${ }^{1}$ Both were major pillars of pagan culture, or paideia, and thus essential elements in the defense of paganism against increasingly powerful and repressive Christian opponents. It is easy to imagine that, under these circumstances, paganism was closing ranks and that philosophers and orators united in their efforts to save traditional ways and values. Although there is no doubt some truth to this view, a closer look reveals that the relations between philosophy and rhetoric were rather more complicated. In what follows, I will discuss these relations with a view to the Platonist school of Athens. By "the Platonist school of Athens" I mean the Platonist school founded by Plutarch of Athens in the late fourth century CE, and reaching a famous end under the leadership of Damascius in 529. ${ }^{2}$ I will first survey the evidence for the attitudes towards rhetoric prevailing amongst the most important Athenian Platonists of the time. I will then consider whether rhetoric played any role in the canonical course of study at the Platonist schools of Athens and Alexandria. Finally, I will conclude with some remarks about the philosophical interest that fifth century Platonists had in rhetoric.

\section{Platonist Scholarchs and Rhetoric}

The major heads of the Platonist school of Athens, its founder Plutarch of Athens, his successor Syrianus, the latter's successor Proclus and its last head Damascius, who revived the school after a period of decline, have all been considered, for various reasons, as being engaged in rhetoric. In this section I survey the evidence for such rhetorical activity. I will argue that most of the evidence does not stand up under closer scrutiny and that we know next to nothing about the attitudes that Plutarch and Syrianus displayed towards rhetoric. While we know more about Proclus and Damascius, their attitudes towards rhetoric seem to have been rather negative.

Little is known about Plutarch of Athens, the founder of the school; no complete work of his has survived and we are only left with scattered fragments. ${ }^{3}$ It is possible that he wrote a commentary on Plato's Gorgias. If he did, this would be important for our purposes because Platonists found in the Gorgias detailed discussions of rhetoric

1 I would like to thank Erwin Cook, Larry Kim and Peter Turner for very helpful comments on earlier drafts of this paper.

2 This school is also sometimes referred to as the "Academy" even though there was no institutional link to Plato's school.

3 Fragments and testimonies have been collected in Taormina 1989. 
that hugely influenced their thinking about the topic. Three fragments of the commentary have survived. ${ }^{4}$ The most interesting, fragment 73 , has come down to us in the anonymous prolegomena to Hermogenes' On Issues. ${ }^{5}$ In this fragment, rhetoric is defined as an art that "possesses authority over and is productive of persuasion in political discourse"; it is emphasized that rhetoric deals with persuasion rather than with teaching. ${ }^{6}$ Neither the definition nor the qualification is original and neither displays any specifically philosophical trait; similar definitions can be found in various contemporary technical treatises on rhetoric. ${ }^{7}$ The author of this fragment also claims that rhetoric is the subject matter of the Gorgias, a claim that, as we shall see, was not universally accepted by other Platonists. Unfortunately, we cannot be certain that the author of these fragments is Plutarch of Athens. ${ }^{8}$ It is likely that they belong to a time period after the famous Plutarch of Chaironeia but this does not prove, of course, that they were written by the only other famous Platonist of that name.

The other piece of evidence linking Plutarch to rhetoric is a stele with an inscription in which a certain Plutarch is called a sophist. ${ }^{9}$ Wilamowitz was the first to identify the dedicatee of the stele with our Platonist. This identification, if correct, might suggest the interesting claim that Plutarch was not only a teacher of philosophy but also of rhetoric. It does so if we further assume that the word "sophist" on this stele means "teacher of rhetoric" as is often the case. Yet whether it here means "teacher of rhetoric" is not clear. Indeed, it is more likely, as Watts thinks, that Plutarch was called a sophist, not in the sense of teacher of rhetoric but rather in the sense of wise person. For using the word "philosophos" in this inscription would not have been possible for metrical reasons and it might well be, as Watts suggests, that the word "sophist" was employed as the next best designation. ${ }^{10}$ If this is so, then the word "sophist" is not referring to rhetoric at all. Hence, our investigation delivers the first negative result: we do not know anything for certain about Plutarch's attitude towards rhetoric.

4 Fr. 73-75 Taormina.

5 On Issues was one of late antiquity's most important technical treatises on rhetoric, part of the socalled corpus Hermogenianum, a set of technical treatises on rhetoric originating in the second century $\mathrm{CE}$, which, between the second and the fifth centuries, became the foundation of rhetorical education and remained so well into Byzantine times. See Heath 1995.

6 Fr. 73 Taormina $=R G$ 7.1.33.28-34.5.

7 For a discussion of the definition and division of rhetoric in late antiquity see Spengel 1863.

8 Beutler 1938 and 1951 defends the view that the commentary was written by Plutarch of Athens but Taormina 1989, 253f. classifies the fragments as dubia.

9 The most prominent use of the word "sophist" in late antiquity was to refer to teachers of rhetoric (Kennedy 1983, 133). Yet note that this was not the only sense of the word "sophist." I will not engage in the debate as to whether all or most sophists (in the prominent sense) were exclusively or mostly teachers or whether they also had important political functions (for this discussion see Brown 1992, $30 \mathrm{f}$. and Van Hoof 2010).

10 IG II/III ${ }^{2}$ 4224; Kaibel 1878, 910; Sironen 1994, 50 -51; Watts 2006, 94. 
Plutarch was succeeded by his pupil Syrianus, who is the author of an important commentary on Aristotle's Metaphysics. At first sight, Syrianus looks more promising because we possess two commentaries on technical rhetorical treatises belonging to the corpus Hermogenianum, one on On Issues and another on On Ideas, attributed by the manuscripts to one Syrianus Sophista. If the sophist is identical with the famous philosopher Syrianus, as many scholars believe, then we might have a first piece of secure evidence for a close connection between philosophy and rhetoric at the Platonist school. ${ }^{11}$

Rabe, the editor of the two rhetorical treatises by Syrianus Sophista, was the first to discuss the arguments in favor of identification. ${ }^{12}$ Rabe did not aim, however, at proving their identity; he only wanted to establish that the arguments against identity are not conclusive. ${ }^{13}$ While I agree with Rabe that the evidence allows for the possibility of identity, it seems to me that we have no compelling reason to assume that they were actually identical. First, the Platonist Syrianus is in many ancient sources called "Syrianus, the philosopher" while the author of the rhetorical treatises is called "Syrianus, the sophist." It is true, of course, as Rabe observes, that this does not conclusively prove their non-identity. But it is still remarkable that the Platonist is almost always explicitly called "the philosopher" and that in most cases where the appellation "the philosopher" is missing, the context makes it quite clear that the philosopher is being referred to. If we assume two distinct Syriani, we can easily explain why later authors referred to the famous Platonist as "the philosopher Syrianus"; they wanted to ensure that he would not get confused with the sophist of the same name. ${ }^{14}$

11 Proponents of identity are, among many others, Praechter 1932a, col. 1732 and Kennedy 1983, $109-112$.

12 For an interesting lexical detail that might be taken to indicate identity, see Heath 2009, 145. 13 Rabe 1893, iv-vii; see also Sandys' review of Rabe where he carefully states that Syrianus "is possibly, though not certainly, the Neo-Platonist of that name" (Sandys 1893, 422).

14 Rabe suggests that Syrianus may first have been a sophist and only later a teacher of philosophy. Now since the commentary on On Ideas is dedicated to the author's son and since this fact has led scholars to assume that Syrianus at the time of penning this commentary must have been at least forty years old, we may face a further problem: Syrianus must have remained a sophist into his forties, before becoming a teacher of philosophy. However, Rabe convincingly argues that this was possible since it is also generally agreed that the commentary the philosopher Syrianus wrote on Aristotle's Metaphysics was written late in his life. Perhaps Syrianus was a victim of Plutarch's longevity and thus not able to support himself as a philosopher until the latter's death (or at least until Plutarch's retirement). Syrianus would then have given up his job as a sophist and become a teacher of philosophy. Westerink 1964, 176 thus maintains that "Syrianus ... has left rhetorical writings, probably less because of the attraction the subject had for him than because the long life of his predecessor made it necessary for him to find some other occupation." (See also Heath 2004, 74). This is possible. We are ill-informed about the financial situation of individual members of the school. Yet we do not, to my knowledge, possess any evidence to show that members other than the head of the school had to make a living outside the school. 
Let us now look at the rhetorical commentaries to see whether Syrianus Sophista displays the knowledge of Platonism that would make an identification with the Platonist likely. To start with, it is evident that the author knew Plato's dialogues well; he often cites, or alludes to them. But his interest in and knowledge of Plato need not have been philosophical, for sophists in late antiquity were deeply impressed by Plato's style. Hermogenes, for example, considered Plato's writings exemplary of the panegyric species of rhetoric. ${ }^{15}$ Hence, it is not surprising that a teacher of rhetoric would be intimately familiar with his dialogues.

An example may illustrate this. As Richtsteig long ago demonstrated, the famous fourth century sophist Libanius was well acquainted with Plato's work. ${ }^{16}$ He even wrote an Apology of Socrates. But many scholars believe that Libanius was not at all interested in philosophy. ${ }^{17}$ Accordingly, the point of his Apology of Socrates was to defend not a philosophical life in the strict sense but paganism. ${ }^{18}$ A significant interest in Plato thus need not imply even a mild interest in philosophy. ${ }^{19}$

A second piece of evidence is that the sophist Syrianus not only knew his Plato well but also was familiar with contemporary Platonism. He begins his commentary on On Issues with the statement that not only sophists but also many Platonists have written commentaries on Hermogenes. ${ }^{20}$ Moreover, as Heath points out, Syrianus announces about a quarter of the way through the commentary on On Issues that from that point on he would abandon Hermogenes and follow the Platonists Evagoras and Aquila. ${ }^{21}$ This evidence shows his knowledge of contemporary Platonism. However, this need not imply a philosophical education, for we have to distinguish two ways in which the word "Platonism" is used. Its core sense is the philosophical view we are familiar with from writers like Plotinus and Proclus. Yet "Platonism" is also used in a wider sense as the world-view of the pagan elite in late antiquity. Being a Platonist in the latter sense does not necessarily imply being a philosopher or having a philosophical education. Even where Syrianus follows Evagoras and Aquila, his commentary is a rhetorical piece that, as far as references to Platonism are concerned, could have been written by someone without training in philosophy.

Finally, there is a more convincing sign of philosophical erudition in Syrianus' rhetorical commentaries: Syrianus must have been familiar with some of Aristotle's writings. He knew Aristotle's logical writings; he also uses some technical terms that

15 Hermogenes, Id. 387. Demosthenes, on the other hand, was considered the master of the judicial and deliberative species. See Rutherford 1992.

16 Richtsteig 1918a.

17 von Christ 1924, 996; Cribiore 2007, 151 n.79.

18 Markowski 1910, $169 \mathrm{f}$.

19 Similar things can be said about further sophists, such as Himerius (see Richtsteig 1918b and Richtsteig 1921). However, other Platonist sophists, such as Sopater, had a thorough education in philosophy (see O’Meara 2003, 209-211).

20 Syrianus, in Herm. 2, p.1.6 Rabe.

21 Syrianus, in Herm. 2, p.56.16-24; Heath 2004, 72. 
have their origin in Aristotle's Metaphysics (on which the philosopher Syrianus commented). It is thus fair to assume that the sophist Syrianus did indeed have some philosophical background. However, this still falls short of demonstrating that he was identical with the famous philosopher.

For a further reason that we cannot necessarily assume identity of the sophist with the philosopher is that we know of another Syrianus with philosophical interests: Syrianus the younger (as Praechter calls him), who is mentioned once in Damascius' Life of Isidorus. Damascius tells us that "Isidorus urged Syrianus and Hegias to restore philosophy which was now wasting away, as was their duty."22 For chronological reasons, we can be certain that the younger Syrianus mentioned by Damascius is not identical with the famous Platonist. ${ }^{23}$ Yet he was clearly a philosopher, for otherwise Isidorus would not have urged him to restore philosophy. Unfortunately, we do not know of any official appointment that he might have had-as a philosopher or in any other capacity. Now I am not claiming that the younger Syrianus is in fact identical with the sophist Syrianus; I do not believe that we possess any evidence to prove this. However, I do not see any better evidence to equate the sophist with the elder Syrianus. On the contrary, if I had to place a wager on whether the elder or the younger Syrianus is the sophist (without a third option), then, on present evidence, my money would be on the younger. But in any case, we do not know whether the philosopher Syrianus was ever engaged in teaching rhetoric, nor do we have sufficient evidence to show that he wrote commentaries on rhetorical works.

We are better informed on the relation of Syrianus' successor Proclus to rhetoric. This is mainly due to the biography written by his pupil Marinus. ${ }^{24}$ After acquiring the moral virtues (as Marinus tells us) and receiving a primary education as well as studying with a grammarian, Proclus moved to Alexandria in order to complete his grammatical education and to study rhetoric with the sophist Leonas. ${ }^{25}$ Marinus tells us that the young Proclus very much liked rhetoric until he received his first taste of philosophy: on a trip to Byzantium, a fellow traveler introduced him to philosophy, and, as a consequence of this encounter, he said goodbye to rhetoric in order to devote himself to the study of philosophy. This interest brought him to Athens.

It is worthwhile to spend a moment on Proclus' arrival in Athens, masterfully described by Marinus, because this scene provides a fascinating glimpse of everyday

22 Damascius, Isid. fr. 151e Athanassiadi; Athanassiadi’s translation (except for “Isidorus” where she has "Isidore").

23 Praechter 1932b col. 1775. Praechter suspects that the great Syrianus might often have been called "the great" in order to distinguish him from the younger. Praechter further conjectures that the younger Syrianus is the son of the great Syrianus.

24 For the following see Marinus, Procl. § 8-11.

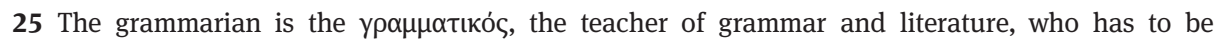
distinguished from the $ү \rho \alpha \mu \mu \alpha \tau \iota \sigma \tau \eta \dot{s, ~ t h e ~ t e a c h e r ~ o f ~ p r i m a r y ~ e d u c a t i o n . ~ T h u s, ~ a ~ g o o d ~ u p p e r-c l a s s ~}$ education in late antiquity consisted of a sequence of three stages: primary education-grammarrhetoric. See Kaster 1983, 323-326; Cribiore 2001, $37 \mathrm{f}$. 
interaction between sophists and philosophers. When Proclus' ship put into port in Piraeus, Nicolaus, a student of rhetoric and future sophist in Constantinople, met him and brought him to Athens where the Platonist scholarch Syrianus and Nicolaus' teacher Lachares, one of the best known sophists of the fifth century, were awaiting him. ${ }^{26}$ Although our source does not tell us so explicitly, it is likely that Lachares and Syrianus decided to send Nicolaus to fetch Proclus from Piraeus because both young men hailed from Lycia, so that Nicolaus' company would have eased Proclus' arrival in a foreign city. ${ }^{27}$ This scene plainly suggests friendly and perhaps even cordial relations between at least some philosophers and sophists. A stronger interpretation, however, namely that they were in their respective functions also working together, should be resisted; for, as Marinus tells us, Lachares was deeply interested in philosophy and himself a student of Syrianus. ${ }^{28}$ Thus, Lachares was a sophist who was pursuing a second education in philosophy. ${ }^{29}$ It is likely that this, rather than his status as a sophist, was the reason for his presence when Proclus arrived in Athens.

Whereas the Athenian sophists were keen on winning Proclus as a pupil, he "despised the rhetorical schools there as well." 30 The "as well" indicates that he already felt the same way in Alexandria; this in turn indicates that he did not dislike the Athenian schools of rhetoric in particular but rather rhetoric itself. Hence, although Proclus did possess a rhetorical education, he was no longer actively interested in rhetoric by the time he had decided to devote his life to philosophy.

We do not know much about Proclus' immediate successor Marinus and the scholarchs between Marinus and Damascius. Yet we know for certain that Damascius was indeed a teacher of rhetoric; like Proclus, however, he decided to give up rhetoric when he converted to philosophy. ${ }^{31}$ Damascius, like nearly every educated person in late antiquity, had received rhetorical training in his youth. ${ }^{32}$ After spending three years studying rhetoric with the sophist Theon in Alexandria, ${ }^{33}$ he started

26 For Lachares see Studemund 1888; Graeven 1895; Radermacher 1921; Kennedy 1983, 167 f.; Puech 2000, 324-26.

27 Marinus, Procl. $\S 14$. Proclus was born in Byzantium but both his parents were Lycians. They moved back there after Proclus' birth (Marinus, Procl. § 6). Proclus himself is often referred to as a Lycian in our sources, for example, by Simplicius (in Phys. 404.16).

28 Proclus was to become his fellow student.

29 Damascius considered Lachares not a particularly gifted sophist and "rather slow in intellectual pursuits." Yet because of his virtuous character (and not because of his intellectual achievements!), Damascius thinks that he is "worthy indeed of being called a philosopher rather than a sophist." See Damascius, Isid. fr. 62 Athanassiadi.

30 Marinus, Procl. $\S 11$.

31 The Suda (s.v.), not always a reliable source, calls Marinus "philosopher and rhetor," but we do not have any further indication that Marinus ever taught rhetoric. Marinus' successor was Hegias or Zenodotus, possibly both. The school declined after Marinus' death until Damascius became its head but we are ill informed about the period between Marinus and Damascius.

32 Heath 1995, 1f. A notable exception was Isidorus who greatly influenced Damascius' intellectual development. See Damascius, Isid. fr. 34c, fr. 37d, fr. 48b, fr. 106 Athanassiadi. See O’Meara 2006. 33 This Theon might be the author of extant progymnasmata. 
teaching rhetoric, and, if Photius is to be trusted, did so for nine years though it may have been only six. ${ }^{34}$ Looking back at his days as a sophist, Damascius states in his Life of Isidorus:

How pernicious an activity was rhetoric, focusing all my attention to the mouth and the tongue and turning it away from the soul and from blissful and divine lessons which purify it. Realizing this, I was sometimes distracted from my rhetorical exegeses...

fr. 137b (Athanassiadi)

How precisely Damascius' transition from rhetoric to philosophy came about we do not know. It is likely that it occurred under the influence of Isidorus, whose character is nicely displayed in this fragment: "Leaving to others the graceful display of words, he occupied himself with revealing the things themselves, pronouncing thoughts rather than words; indeed it was not so much thoughts that he brought to light as the very essence of the things themselves." 35

What Damascius says about rhetoric in the fragment discussed earlier (fr. 122d Athanassiadi) displays a similar sentiment. Even as a teacher of rhetoric, he was tired of it and clearly saw the reason for his dissatisfaction: rhetoric is concerned with expression and not with the content of what is expressed. The exercise of rhetoric made it impossible-or at least very difficult-for Damascius to devote his time to what he considered truly important, namely the soul and its purification. The "blissful and divine lessons" that lead to the soul's purification belong, of course, to philosophy. Thus, Damascius, like Proclus before him, felt a sharp contrast between rhetoric and philosophy. He left rhetoric behind and at the Athenian school studied mathematics with Marinus and philosophy with Zenodotus, who had been Proclus' favorite student. ${ }^{36}$

This brief survey of the attitudes of the major fifth century AthenianPlatonists towards rhetoric shows that there is no good reason to assume that relations between rhetoric and philosophy were close. In fact, the few explicit statements about rhetoric that have come down to us reveal a negative attitude. However, we have also seen that most Platonists, just like other educated people at the time, had been thoroughly trained in rhetoric. It seems likely that their rhetorical training preceded their philosophical studies at the school. In order to confirm this impression, our next task will be to investigate the school curriculum. We will have to ask whether or not it includ-

34 Photius, Bibl. Cod. 181 (see also fr. 122d Athanassiadi). Photius might have misread Isid. fr. 137b Athanassiadi where Damascius tells us that he had spent nine years in rhetorical pursuits. It is unclear whether Damascius only refers to his teaching years or his student days as well. So his teaching career in rhetoric spanned either six or nine years.

35 Damascius, Isid. fr. 37d Athanassiadi. Translation slightly modified. The fragment also shows what is evident throughout the Life of Isidorus: that the philosopher Damascius had not forgotten his rhetoric and continued to make use of it. See also O’Meara 2006.

36 Damascius, Isid. fr. 99b Athanassiadi. 
ed training in rhetoric or, more generally, whether rhetoric played any role in it (and if so, what precisely its role was).

\section{Rhetoric and the Curriculum}

It is well known that a Platonist education in late antiquity followed a more or less canonical curriculum. ${ }^{37}$ While there are many open questions, its main outlines seem reasonably clear. ${ }^{38}$ New students would often study some exhortative reading, possibly an oration by the classical orator Isocrates, the so-called Pythagorean Golden Verses or Epictetus' Encheiridion. They would then move on the "lesser mysteries" of Aristotle, ${ }^{39}$ starting with the Organon (including Porphyry's Introduction) to learn logic, before moving on to ethics, physics and finally theology, i.e. metaphysics. ${ }^{40}$ The study of Aristotle served as preparation for Plato of whom students read twelve dialogues in a fixed order first established by Iamblichus. ${ }^{41}$ The order of the reading lists was not necessarily determined by the idea of moving from easier texts to more difficult ones but rather by the aim of the Platonist life, which is the divinization of the soul. ${ }^{42}$ Accordingly, both lists were organized in such a way as to prepare students for the ascent and to guide their souls towards the divine.

Interestingly, questions concerning the role of rhetoric arise at all three levels of the philosophical curriculum: at the introductory level students would often read Isocrates, and we need to consider whether this was for rhetorical purposes. At the next, Aristotelian, stage, we will examine the possibility that Aristotle's Rhetoric was one of the "lesser mysteries" assigned. Finally, we know that the Gorgias and the Phaedrus, the two Platonic dialogues most concerned with rhetoric, belonged to the Platonic part of the curriculum and we will explore whether they were studied with a view to rhetorical training.

We know that three of Isocrates' orations were read: To Demonicus, To Nicocles, and Nicocles. ${ }^{43}$ The function of these orations was exhortatory, specifically to encour-

37 Hadot 1979; Hoffmann 2000, 611-614; O’Meara 2003, 61-68.

38 For this discussion I shall assume that what we know about the Platonist school of Alexandria also applies to the Athenian school. It is generally agreed nowadays that there are no crucial dogmatic differences between the two schools (see Hadot 1978 and 1992 against Praechter 1910).

39 For Aristotle as a preparatory reading for Plato and the expression "lesser mysteries" see Marinus, Procl. § 13.

40 For the order in which to read Aristotle's work, see also Sorabji 1990, 6. Mathematics will also have had its place. We know that Damascius studied mathematics with Marinus (Phot. Bibl. Cod. 181). 41 Westerink 1962, xxxvii-xli; Festugière 1969.

42 O'Meara 1992, in particular 504. It should be mentioned that, after the philosophical curriculum, students would read the holy pagan scriptures: the Orphic Hymns and the Chaldean Oracles. See Hoffmann 2000, 613f.

43 Late ancient Platonists thought all three were authentic. I shall not discuss whether or not they were right. 
age young people to live a philosophical life. Unlike the later ethical readings, such as the Nicomachean Ethics, they were not primarily used for ethical reflection, a point that is nicely illustrated by Damascius' Life of Isidorus: Damascius there remarks that Severianus, a Damascene nobleman with philosophical interests had once explained Isocrates' political orations to him in his youth, not, as Damascius emphasizes, in rhetorical terms but with a focus on their philosophical (which here means: moral) content. ${ }^{44}$ Even though Severianus was not teaching at the school and was not even a professional philosopher, it seems reasonable to assume that Isocrates was read at the school in the same spirit. Accordingly, that orations by Isocrates were read does not indicate that the interest in these orations was rhetorical; they were simply read because of their moral content and because of their power to motivate the young to pursue philosophy.

If we bear in mind, as I mentioned earlier, that beginning philosophy students typically entered the school with a completed rhetorical education, it is likely that they had already read other orations by Isocrates as part of their training, since he was one of the orators that sophists wanted their students to imitate. Hermogenes, for example, explicitly acknowledges him as one of the ten canonical orators and, in his discussion of style, applauds him for the way he creates beauty. ${ }^{45}$

While modern scholarly editions of Aristotle's organon consist of the six familiar logical works (often with Porphyry's Introduction), ${ }^{46}$ the late ancient organon also included his Rhetoric and Poetics. ${ }^{47}$ We do not know the origin of this classification, but it seems to have been well-established by the time of Ammonius, student of Proclus and teacher in Alexandria. ${ }^{48}$ The issue that Platonists faced was to explain what precisely (if any) the role of Aristotle's Rhetoric in their logic course should be. Ammonius was acutely aware of this issue; he did not see any function for the Rhetoric in the study of syllogisms. ${ }^{49}$ He bases this on the claim that Aristotle distinguishes three species of syllogism: apodeictic, dialectical, and sophistical. The first species is covered in the Posterior Analytics, the second in the Topics and the third in the Sophistical Refutations. ${ }^{50}$ There is thus no room for Rhetoric and Poetics. Ammonius'

\footnotetext{
44 Damascius, Isid. fr. 108 Athanassiadi. For the role of the reading of Isocrates see Hadot 1978, 160 4; Hoffmann 2000, 612; Menchelli 2007 and 2008.

45 Hermog. Id. 298f; 395-403. See Rutherford 1992.

46 For influential modern editions of the organon see, for example, Pacius 1597 and Waitz 1844. In modern editions the organon consists of Categories, De Interpretatione, Prior Analytics, Posterior Analytics, Topics, Sophistical Refutations, and often (but not always) Porphyry's Introduction.

47 See Walzer 1934; Black 1990, 17-51. For the following considerations I am much indebted to Black 1990.

48 Moraux 1951, 179. Moraux also points out that already the so-called Middle Platonist Alcinous considered the Rhetoric a study of imperfect syllogisms, based on Aristotle's rhetorical sullogismos and thus as part of Aristotle's logic (Moraux 1951, 181-183).

49 For the following, see Ammonius in APr. 11.22-38; Black 1990, 31-33.

50 Categories, De Interpretatione, and Prior Analytics were considered preliminary studies for syllogistic.
} 


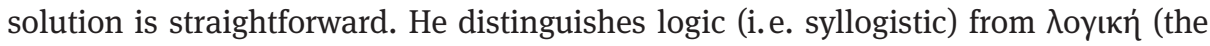
study of $\lambda$ óyos quite generally), claims that the former is only a part of the latter and concludes that, since Rhetoric and Poetics are not syllogistic, they must belong

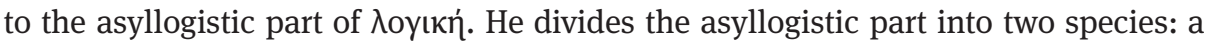
metrical one, studied in the Poetics, and an ametrical one, studied in the Rhetoric. Aristotle's Rhetoric thus belongs to the Organon but it does not belong to logic (in what we would call the traditional sense). This solves the classificatory problem in an elegant way. ${ }^{51}$ Since the Organon was used to teach logic, Ammonius had no place for the Rhetoric in his teaching. The fact that he kept the Rhetoric in the organon simply reveals a conservative attitude.

Olympiodorus, a later Alexandrian Platonist and possibly a student of Ammonius, disagreed with Ammonius and considered the study of the Rhetoric necessary because of its utility in detecting unsound syllogisms. In his answer to the question of why students should study Sophistical Refutations, Topics, Rhetoric and Poetics, he claims that, just as a student of medicine must know not only health but also illnesses, so a student of syllogistic must be able to detect sophistical syllogisms that aim at overturning and concealing the truth. ${ }^{52}$ This account is quite different from Ammonius' in that it presupposes that the Rhetoric (just as the other works mentioned above) is concerned with certain kinds of syllogisms, but with kinds of syllogism that are in one way or other deficient.

An attempt at explaining this deficiency in more detail was made by another Alexandrian commentator, Elias, who argues that there are five kinds of syllogism, one of which is called rhetorical and is the object of the Rhetoric. ${ }^{53}$ Elias tries to explain the differences between kinds of syllogism with reference to the truth-values of their premises: While the premises of the apodeictic syllogism are true, the premises of the rhetorical syllogism are "equally true and false." 54 Accordingly, he sees the difference between kinds of syllogism not in their form but in their matter. Thus, rhetorical syllogisms are valid and the deficiency of this type of syllogism is due to their premises being equally true and false. What he means by "equally true and false" is at first sight not clear. It is unlikely that he thinks that, for each rhetorical syllogism, the number of true premises equals the number of false premises (i.e. that each rhetorical syllogism has precisely one true and one false premise). A more likely interpretation is that, while the premises of apodeictic syllogisms are always true, those of rhetorical syllogisms are as often false as they are true.

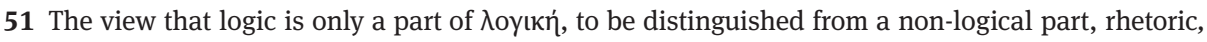
can already be found in Hellenistic Stoicism. See Barnes 1999, 65-67.

52 Olympiodorus, Proll. 8.19-27.

53 Elias, in Cat. 116 f.; in APr. 139.10 f. For a discussion see Ebbesen 1981, 102-105. Aristotle talks of a "rhetorical $\sigma 0 \lambda \lambda$ оуı $\sigma$ ó,", and considers it indeed the heart of his rhetorical theory: the enthymeme (Rhet. 1356a35f.). See Burnyeat 1994. Yet it is quite different from Elias' rhetorical syllogism.

54 The other three kinds of syllogism are poetical (all premises false), dialectical (more true and less false), sophistical (more false and less true). 
This gives rise to the question of how to distinguish rhetorical syllogisms (which are equally true and false) from dialectical (more true than false) and from sophistical (more false than true) ones. Ebbesen refers to a medieval manual of logic, the Anonymous Heiberg, whose logic might go back to the Alexandrians. ${ }^{55}$ The Anonymous Heiberg names different sources of premises for the five kinds of syllogism. Rhetorical syllogisms have non-rational opinion as their source, which is a better source than imagination (more false than true) but not as good a source as rational opinion (more true than false). Thus the difference between these three kinds of syllogism seems to lie in the degree of epistemic reliability of their corresponding cognitive faculties. ${ }^{56}$

The details of this remain obscure and we cannot be certain whether the explanations of the Anonymous Heiberg were known in Athens and Alexandria. Yet this does not matter for our purposes because in Ammonius' view the Rhetoric was not part of the lesser mysteries of the school curriculum precisely because it had nothing to do with syllogistic. According to the view we find in Olympiodorus and Elias, on the other hand, the Rhetoric had a function in syllogistic and its inclusion in the curriculum nothing to do with rhetoric per se. Either way, we have no indication that Aristotle's Rhetoric was used in the school for rhetorical purposes.

Let us move to the Platonic curriculum and briefly discuss the function of the Gorgias and the Phaedrus therein. We are in the fortunate position of possessing commentaries on both works: Olympiodorus commented on the Gorgias and Hermias on the Phaedrus. The Gorgias was the second dialogue to be read (after the Alcibiades) and thus belonged to ethical education. More precisely, according to the ancient commentators it was concerned with political virtues. ${ }^{57}$ The Phaedrus was number eight on the list, between the Statesman and the Symposium. The author of the anonymous Prolegomena tells us that both the Phaedrus and the Symposium deal with theological questions and, in keeping with this, Hermias argues in his commentary on the Phaedrus that its topic (skopos) is Beauty. ${ }^{58}$

It is interesting to note that both commentators, when discussing the topic of their respective dialogues, consider and reject the view that it is rhetoric. Readers, we are told, who mistakenly think it is, are taking a part for the whole. Olympiodorus reports that these interpreters base their claim on the observation that Socrates talks with Gorgias about rhetoric but do not take into account that this discussion is only part of the dialogue and cannot therefore be the topic of the whole..$^{59}$ In the same vein, Hermias complains that such interpreters only focus on a part of the Phaedrus

55 Ebbesen 1981, $102 \mathrm{f}$.

56 This is presumably the source of the modern idea that the Topics deals with probable proofs. The premises of these proofs are more likely to be true than to be false, on this reading. For the modern idea, see, for example, Zeller 1921, 72.

57 Olymp. in Grg. pr. 4; Anon. Prol. ch. 10. Westerink 1962, XL; O’Meara 2003, 67 f.

58 Anon. Proll. ch. 10; Hermias, in Phdr. 11.19f.

59 Olymp. in Grg. pr. 4. 
(the beginning and the end of the dialogue) and mistakenly believe they have found the topic of the whole. ${ }^{60}$ Thus, the reading of neither of these dialogues functioned as a form of rhetorical education.

To conclude, we have seen that rhetorical texts, such as some orations by Isocrates, possibly Aristotle's Rhetoric, and the two Platonic dialogues just mentioned played, in different ways, a role in the Platonist curriculum. Isocrates' orations were used in order to exhort and morally train students in a preliminary and nontheoretical way. Aristotle's Rhetoric, if it was used at all, served as part of training in logic in that it provided the foundation to understanding one kind of (materially) deficient syllogism. Plato's Gorgias and Phaedrus were read as dialogues about political virtue and beauty respectively. None of these texts were read to educate students in rhetoric. This result is in keeping with the claim made earlier that Platonist freshmen already entered the school with a degree in rhetoric (so to speak).

\section{Rhetoric and Philosophy}

In the first section of this paper I argued that we do not know much about the views of Athenian Platonists on rhetoric and that the two Platonists whose attitudes we know, Proclus and Damascius, do not seem to have thought very highly of it. Damascius, as we have seen, grew tired of rhetoric because of its focus "on tongue and mouth" and because it prevented him from devoting himself to the "purification of the soul." Yet when turning to the content of the two commentaries on the Platonic dialogues introduced above, we find a different and rather positive picture. Both Hermias and Olympiodorus emphasize, following some Platonic passages, how true (or perfect) rhetoric plays an important and positive role. Our final task is thus to explain what this positive role is and how it can be reconciled with the negative attitudes displayed by Proclus and Damascius.

I wish to rule out one potential solution right from the start, namely that the difference is one between Athens and Alexandria. After all, both commentaries were written by Alexandrians while the negative attitudes were expressed by Athenians. I do not think, however, that this is a satisfactory solution. Many Alexandrian Platonists had studied in Athens before they took on their teaching positions in Alexandria; thus we would need a good reason to assume that the Alexandrians deviated in this respect from what they had learned in Athens. ${ }^{61}$ If there is any major difference between the two schools at all, it would seem to be grounded in their differing attitudes towards Christianity. However, it is unclear how this difference would give rise to opposing views on rhetoric. I concede, of course, that this is not conclusive proof. Yet I think we can reconcile the negative attitudes of the Athenians with the positive readings of the Alexandrian commentators without referring to differences between the

60 Herm. in Phdr. $10.27 \mathrm{f}$.

61 See Hadot 1978 and Hadot 1992 against Praechter 1910. 
two schools. But first let us briefly examine what the two commentators have to say about rhetoric.

Both commentaries follow Plato in distinguishing between true and perfect rhetoric on the one hand and popular and false rhetoric on the other. Olympiodorus, following the Gorgias, explains that false rhetoric is the rhetoric of the flatterer. It does not aim at the good, the fine and the useful. ${ }^{62}$ Instead, it only aims at bringing about pleasure and is thus directed towards the lowest of the three Platonic soul parts and its irrational desires. True rhetoric, by contrast, is the servant of the true statesman. The true statesman aims at improving the souls of the citizens and possesses the corresponding knowledge. Thus, he knows what is best for the citizens and the city and, accordingly, the true orator's service consists in persuading the citizens of what the true statesman knows is in their best interest. ${ }^{63}$

Olympiodorus also mentions a third kind of rhetoric, which he considers intermediate between the true and the flattering type and finds exemplified by such orators as Demosthenes, Pericles, and Themistocles. ${ }^{64}$ Instead of listening to the truth spoken by the true statesman, they were only carrying out the wishes of the citizens and are, for this reason, not true orators. Yet unlike flatterers, these intermediate orators saved the city; thus their persuasive work brought about the right result. ${ }^{65}$ Tarrant suggests that it might have been important to Olympiodorus (and perhaps to other Platonist teachers) to introduce this third kind of rhetoric for pragmatic reasons. As mentioned earlier, many of their students would eventually have to make a living as sophists after their philosophical studies and the intermediate type of rhetoric would give them a justification for doing so. ${ }^{66} \mathrm{I}$ shall come back to this below.

Hermias largely agrees with Olympiodorus on the role of rhetoric. He emphasizes the Platonic idea found in the Phaedrus that rhetoric is a type of psuchagogia that aims at winning souls for the good. Like Olympiodorus, he argues that true rhetoric is thus based on proper understanding of what is good and fine. Yet Hermias gives us a more detailed account of the relationship between philosopher and orator than Olympiodorus. In doing so, he relies on ideas found in the Republic, and is concerned with the ascent and descent of the philosophers. By “philosopher," Hermias

62 A variation of the three aims that the flatterer misses, can be found in Elias who assumes that the three species of rhetoric (judicial, deliberative, and epideictic) aim at the just, the useful, and the fine, respectively (Elias, in Porph. 21.28-34). It was also common to associate each species with a Platonic soul part, respectively (e.g. $R G$ 14.58.24-27). See Montefusco 2010, $254 \mathrm{f}$.

63 See also Hermias, in Phdr. 242.11-15 where we learn that true rhetoric is guided by truth and aims at making the citizens good and fine. In persuading the citizens, the true orator should use any means necessary, using different arguments depending on the addressee of his speeches just as the doctor applies a variety of remedies and uses for each particular patient the remedy that heals their particular suffering.

64 See also Hermias, in Phdr. 221.9-24.

65 Olymp. in Grg. 1.13, 33.3.

66 See Tarrant in Jackson et al. 1998, 17-20. 
explains, we primarily mean someone who dwells in the noetic realm and contemplates the intelligible world and God. In other words, the philosopher (in the primary sense) has left the Cave and is spending his time in contemplation. However, these philosophers have to descend and when they turn their attention to the city in order to care for it, they assume a new and practical function. ${ }^{67}$ Instead of using the term "philosopher kings," Hermias calls them, equally following Plato, statesmen. The statesman, in turn, becomes a true orator when "he persuades the people of the city to do what is necessary." ${ }^{68}$ The fact that Hermias, by contrast to Olympiodorus, identifies the true orator and the true statesman does not matter, for the major point that both commentators drive home is the same: true rhetoric must be informed by the understanding of how the city ought to be governed. Yet this is only available to someone who has been in the noetic realm, and who possesses the corresponding knowledge. Here's how Hermias states it: "Because he knows, due to his contemplation, the truth, he persuades them to do the right thing and what is good for them." 69 Thus, ideally, rhetoric, for Platonists, possesses an important function in the political sphere: it is necessary for the happiness of the city and of the citizens. But true rhetoric presupposes ascent to the noetic realm and a proper understanding of the truth. Only with this divine knowledge can there be such a thing as a true orator.

This brings me back to Proclus and Damascius. Their negative remarks about rhetoric belong to a time in their lives when they had only just begun to engage in philosophical studies. When Damascius complains that rhetoric prevented him from devoting himself to the purification of his soul, he means that it prevented him from starting his journey out of the Cave. His complaint is thus perfectly compatible with praise of true rhetoric because the latter belongs to the descent back into the Cave. Before one has reached the Platonist aim of purifying and deifying the soul, rhetoric is nothing more than a distraction. For, as Hermias explains, a soul that seeks noetic beauty needs "solitude and quietude." But orators dwell in the material realm and cannot possibly spend their lives in solitary contemplation. ${ }^{70}$ This not only explains Damascius' attitude but also why rhetoric does not have a role to play in the Platonist curriculum. For, as we have seen, the curriculum aims at the ascent to the divine realm to which rhetoric has nothing at all to contribute.

To conclude, I wish to come back to those sophists of the fifth and sixth centuries who had a Platonist background and a proper philosophical education. We are able to explain the existence of such sophists by their being many more teaching jobs available in rhetoric than in philosophy. Accordingly, many philosophy graduates embarked on careers as professional sophists. How should a Platonist sophist

67 The reasons for the descent in the Republic are discussed in Caluori 2011. For later Platonist views on this topic see O'Meara 2003, 73-86; for Plotinus see Caluori 2005.

68 Hermias, in Phdr. 221.7-16. See also in Phdr. 1.6 where Hermias identifies the true orator with the philosopher.

69 Hermias, in Phdr. 221.17f. See O’Meara 2003, $81 \mathrm{f}$.

70 Hermias, in Phdr. 19.9-22. 
see his position as an orator? Since there were no philosopher kings and thus no true statesmen, they could rightly see neither themselves nor their students as (future) perfect orators. It would be interesting to study in detail whether, and in what way, Olympiodorus' intermediate orator could serve as a model for them. The answer to that question depends on the details of a Platonist political philosophy for a city or a state without factual access to divine knowledge. As O’Meara has shown, Platonists developed such a political philosophy, which was based on the primacy of law. ${ }^{71}$ It is possible that this served Platonist sophists as a framework for their rhetorical activity (based on Olympiodorus' intermediate orators or otherwise). Only when we work out the details of this, will we be able to see what it means to be a Platonist sophist in a philosophically interesting sense. It would also help us better understand the relationship between Platonism and rhetoric in late antiquity and perhaps even show that the practice of rhetoric was more deeply pervaded by philosophical concerns than our current knowledge suggests.

71 O’Meara 2003, 87-115. 
